\title{
MANJ RAZVITA OBMOČJA KOT ELEMENT POLITIKE SKLADNEJŠEGA REGIONALNEGA RAZVOJA V SLOVENIJI: PRETEKLE IZKUŠNJE IN PRIHODNJII IZZIVI
}

\author{
Simon Kušar \\ Oddelek za geografijo, Filozofska fakulteta, Univerza v Ljubljani \\ Aškerčeva 2, SI-I000 Ljubljana \\ e-mail: simon.kusar@ff.uni-lj.si \\ Izvirni znanstveni članek \\ COBISS 1.01
}

\section{Izvleček}

Slovenija ima večdesetletne izkušnje na področju zagotavljanja blaginje prostora, saj so manj razvita območja od leta 1971 dalje stalnica v slovenski regionalni politiki. V članku so predstavljene nekatere glavne izkušnje in temeljni dosežki dosedanje regionalne politike s poudarkom na manj razvitih območjih kot posebnim instrumentom regionalne politike. $\mathrm{V}$ nadaljevanju so opredeljena nekatera temeljna konceptualna vprašanja, na katera bo potrebno odgovoriti pri načrtovanju spodbujanja razvoja manj razvitih območij v prihodnosti.

Ključne besede: regionalno planiranje, regionalni razvoj, regionalna politika, manj razvita območja, Slovenija

\section{LESS DEVELOPED AREAS AS AN ELEMENT OF BALANCED REGIONAL DEVELOPMENT POLICY IN SLOVENIA: PAST EXPERIENCES AND FUTURE CHALLENGES}

\begin{abstract}
Slovenian experiences with place prosperity policy go a few decades back. Less developed areas were introduced in 1971 for the first time and since then they have been continuously used as an instrument of regional policy. The paper presents some major experiences and basic achievements of Slovenian regional policy with the emphasis on less developed areas. Some basic conceptual questions which should be answered in planning further development of less developed areas are adressed later.
\end{abstract}

Key words: regional planning, regional development, regional policy, less developed areas, Slovenia 


\section{MANJ RAZVITA OBMOČJA KOT INSTRUMENT REGIONALNE POLITIKE}

Ekonomski razvoj po 2. svtovni vojni je še povečal razlike v stopnji razvitosti med posameznimi prostorskimi enotami znotraj države in naddržavnih skupnosti. Ekonomski, socialni in prostorski razvoj se je osredotočal predvsem v manjšem številu najbolj razvitih regij, ki jih odlikujejo najustreznejši lokacijski pogoji: geografska lega in položaj, tradicija, naravni viri, zadostno število ustrezno usposobljene delovne sile, raziskovalne organizacije in podobno. $\mathrm{V}$ nasprotju z območji koncentracije so številna območja razvojno zaostajala. Posebej so bila prizadeta periferna območja (v regionalnem, nacionalnem in nadnacionalnem okviru), visokogorska območja in nekatera stara industrijska območja. Značilnosti območij v razvojnem zaostanku so neučinkovita gospodarska struktura, nizki dohodki, visoka stopnja brezposelnosti, depopulacija, staranje prebivalstva, pomanjkljiva oskrba, slabo razvita infrastruktura, omejujoči naravnogeografski dejavniki (velika reliefna energija, ekstremno podnebje, nerodovitna prst, pomanjkanje naravnih virov).

Neravnovesje $\mathrm{v}$ razvitosti med posameznimi prostorskimi enotami lahko pripelje do številnih za državo neugodnih posledic, ki obsegajo ekonomske, socialne, okoljske in politične komponente: zaviranje gospodarskega razvoja države kot celote, nedoseganje ciljev gospodarske učinkovitosti in rasti, finančni primankljaj povezan z izpadom dohodka ter povečanjem izdatkov za socialno pomoč brezposelnim in ljudem z nizkimi dohodki, socialne in politične nemire ter neustrezno ravnanje $\mathrm{z}$ naravnimi viri.

V izogib naštetim problemom so se države odločile, da oblikujejo posebno razvojno politiko, ki temelji na zagotavljanju blaginje prostora (»place prosperity«). S podporo manj razvitim območjem naj bi se povečala gospodarska rast, izboljšalo finančno poslovanje države in uresničevalo osnovna družbena načela ter naloge države zapisane v temeljnih ustavnih listinah. Manj razvita območja so postala poseben instrument regionalne politike. Vanje so se usmerjali vsi ostali instrumenti s ciljem zmanjšanja regionalnih razlik med posameznimi območji. V začetku so bila glavna orodja regionalne politike predvsem subvencije podjetjem za investicije in odpiranje novih delovnih mest. S spremembami regionalne politike v drugi polovici osemdesetih let 20 . stoletja so se $\mathrm{v}$ manj razvitih območjih pripravljali posebni razvojni programi, ki so se izvajali z obilno finančno in organizacijsko podporo države in $\mathrm{v}$ primeru članic Evropske unije tudi s pomočjo sredstev skupne regionalne politike.

\section{PRETEKLE IZKUŠNJE S SPODBUJANJEM RAZVOJA MANJ RAZVITIH OBMOČIJ V SLOVENIJI}

Polarizacija gospodarskega, demografskega in prostorskega razvoja v Sloveniji ima svoje korenine v 2. polovici 19. stoletja, ko se je na območju današnje Slovenije začela razvijati industrija. $Z$ gospodarskim razvojem po drugi svetovni vojni so se razvojne razlike med posameznimi območji v Sloveniji še povečale. Oblikovala so se območja koncentracije prebivalstva s prevlado urbano-industrijske strukture in območja depopulacije $\mathrm{z}$ agrarno strukturo. 
Problem manj razvitih območij se je v začetni fazi regionalne politike reševal le na ravni jugoslovanske federacije. Slovenija je bila glede na razvojno stanje ostalih delov skupne države njen najbolj razviti del. Kljub temu so se regionalne razlike v Sloveniji v sedemdesetih letih 20. stoletja tako povečale, da so republiške oblasti »pod pritiskom javnosti morale priznati, da obstajajo nerazvita območja tudi v Sloveniji in da se regionalne razlike večajo« (Vrišer, 1998, str. 66). S sprejetjem Zakona o ukrepih za pospeševanje razvoja manj razvitih območij so bili storjeni prvi koraki k doseganju skladnejšega regionalnega razvoja v Sloveniji. Temu zakonu je sledilo še več pravnih virov, ki so skušali doseči hitrejši gospodarski, socialni in prostorski razvoj manj razvitih območij.

Pri opredeljevanju in analizi manj razvitih območij so v ospredju vedno naslednja temeljna konceptualna vprašanja: na kakšnih prostorskih enotah se bodo določala problemska območija, katera merila se bodo uporabljala za njihovo opredelitev ter kakšni instrumenti regionalne politike se bodo izvajali v njih. V preglednici 1 so predstavljeni osnovni elementi vseh dosedanjih zakonov, s katerimi se je zagotavljala blaginja prostora, slika 1 pa prikazuje prostorski obseg problemskih območij v Sloveniji ${ }^{1}$.

Temeljne značilnosti slovenske regionalne politike oziroma pomoči manj razvitim območjem so prikazane v naslednjih točkah:

1. Usmerjenost slovenske regionalne politike k manj razvitim (obmejnim) območjem.

Regionalna razvojna politika v Sloveniji je od leta 1971 dalje, ko je bil sprejet prvi zakon o spodbujanju skladnejšega regionalnega razvoja, opredeljevala kot prednostna območja svojega delovanja manj razvita in manj razvita obmejna območja. Leta 1990 je sistem spodbujanja skladnejšega regionalnega razvoja doživel večje spremembe. Prednostna območja regionalne politike so postala demografsko ogrožena območja, ki so se srečevala z negativnimi demografskimi trendi. Zakon o spodbujanju skladnega regionalnega razvoja iz leta 1999 temelji na načelu celovitosti izvajanja regionalne strukturne politike na celotnem ozemlju Republike Slovenije, vendar kot prednostna območja delovanja opredeljuje območja s posebnimi razvojnimi problemi, ki zajemajo manj razvita območja in nekatera stara industrijska območja. Pomoč manj razvitim območjem je z izjemo devetdesetih let 20. stoletja, ko so bila v ospredju demografsko ogrožena območja, stalni spremljevalec slovenske regionalne politike.

2. Pogosto spreminjanje meril za določitev manj razvitih območij ter njihova zapletenost. Merila za določitev območij prednostnega delovanja regionalne politike so z leti postajala vse bolj zapletena. Merila za določitev manj razvitih območij iz leta 1971 so jasna in kratka in vključujejo manjše število socioekonomskih kazalcev. Zakon o pospeševanju skladnejšega regionalnega razvoja v Socialistični republiki Sloveniji (1975) ter njegove spremembe in dopolnitve iz leta 1980 sta prinašala mnogo bolj zapletena merila. Večje

\footnotetext{
${ }^{1}$ Slovensko regionalno politiko lahko glede na opredeljevanje problemskih oziroma manj razvitih območij razdelimo na šest obdobij: 1971-1975; 1976-1980, 1981-1985, 1986-1990, 1991-2000, od 2000 dalje. Na sliki 1 je za vsako območje naselja prikazano, kolikokrat se je uvrščalo med problemska območja, ne glede na to, v katerem časovnem obdobju.
} 
Preglednica 1: Koncept manj razvitih območij v Sloveniji.

Table 1: The concept of less developed areas in Slovenia.

\begin{tabular}{|c|c|c|}
\hline Zakon & $\begin{array}{l}\text { Zakon o ukrepih za } \\
\text { pospeševanje razvoja } \\
\text { manj razvitih območij }\end{array}$ & $\begin{array}{l}\text { Zakon o pospeševanju skladnejšega regionalnega } \\
\text { razvoja v SR Sloveniji }\end{array}$ \\
\hline Leto sprejema & 1971 & 1975 (spremembe $1980,1985,1988)$ \\
\hline Tipi problemskih območij & manj razvita območja & $\begin{array}{ll}\text { - } & \text { manj razvita območja; } \\
\text { - } & \text { manj razvita obmejna območja (1981-1990); } \\
\text { območja v prehodnem obdobju (1981-1990) }\end{array}$ \\
\hline $\begin{array}{l}\text { Merila za določitev } \\
\text { problemskih območij }\end{array}$ & $\begin{array}{l}\text { narodni dohodek na } \\
\text { prebivalca; } \\
\text { \% kmečkega } \\
\text { prebivalstva; } \\
\text { \% zaposlenega } \\
\text { prebivalstva }\end{array}$ & $\begin{array}{ll}\text { - } & \text { družbeni proizvod; } \\
\text { - } & \text { \% zaposlenih; } \\
\text { - } & \text { gibanje št. preb.; } \\
\text { - } & \text { \% predšolskih otrok v VVZ; } \\
\text { - } & \text { \% slušateljev višjih in visokih šol; } \\
\text { - } & \text { \% cest s sodobnim voziščem (1976-1980); } \\
\text { - } & \text { \% k. preb. (1976-1980); } \\
\text { - } & \text { \% gosp. z vodovodom (1976-1980); } \\
\text { - } \quad \text { \% aktivnih osnovnih sredstev (1981-1990); } \\
\text { - } \quad \text { delež primarnega sektorja v družbenem } \\
\text { - } \quad \text { proizvodu (1981-1990); } \\
\text { - } \quad \text { sromet v trgovini na drobno (1981-1990); } \\
\quad \text { (1981-1990) }\end{array}$ \\
\hline $\begin{array}{l}\text { Prostorska enota za } \\
\text { določitev problemskih } \\
\text { območij }\end{array}$ & občina & občina, krajevna skupnost \\
\hline $\begin{array}{l}\text { Območja v Sloveniji, ki } \\
\text { so sodila med problemska } \\
\text { območja }\end{array}$ & $\begin{array}{l}\text { Pomurje, Slovenske } \\
\text { gorice, Spodnje Podravje, } \\
\text { Kozjansko, občini Trebnje } \\
\text { in Črnomelj }\end{array}$ & $\begin{array}{l}\text { Pomurje, Slovenske gorice, Podravje, Haloze, } \\
\text { Kozjansko, Posotelje, Tolminsko, Suha krajina, } \\
\text { Brkini, Zgornje Pokolpje, Bela krajina }\end{array}$ \\
\hline $\begin{array}{l}\text { Delež površine Slovenije, } \\
\text { ki je sodil med } \\
\text { problemska območja }\end{array}$ & $18,9 \%$ & $\begin{array}{l}30 \%(1976-1980) \\
29,1 \%(1981-1985) \\
21,7 \%(1986-1990) \\
\end{array}$ \\
\hline $\begin{array}{l}\text { Delež prebivalcev, ki } \\
\text { so živeli v problemskih } \\
\text { območjih }\end{array}$ & $18,2 \%$ & $\begin{array}{l}20,7 \%(1976-1980) \\
15,6 \% / 1981-1985) \\
16 \%(1986-1990)\end{array}$ \\
\hline $\begin{array}{l}\text { Instrumenti, ki so se } \\
\text { izvajali v problemskih } \\
\text { območjih }\end{array}$ & $\begin{array}{ll}\text { - } & \text { gradnja (družbene) } \\
\text { infrastrukture; } \\
\text { - } \quad \text { davčne, kreditne } \\
\text { olajšave; } \\
\text { - } \quad \text { sofinanciranje } \\
\text { investicijskih } \\
\text { in razvojnih } \\
\text { programov; } \\
\text { - } \quad \text { ukrepi za } \\
\text { pospeševanje } \\
\text { kmetijstva } \\
\end{array}$ & $\begin{array}{ll}\text { - } & \text { kreditne olajšave; } \\
\text { - } & \text { opredeljevanje planskih usmeritev; } \\
\text { - } & \text { ukrepi davčne politike; } \\
& \text { sofinanciranje izdelave razvojnih programov } \\
& \begin{array}{l}\text { Družbeni dogovor o pospeševanju } \\
\text { skladnejšega RR. }\end{array}\end{array}$ \\
\hline
\end{tabular}




\begin{tabular}{|c|c|}
\hline $\begin{array}{l}\text { Zakon o spodbujanju razvoja demografsko } \\
\text { ogroženih območij v Republiki Sloveniji }\end{array}$ & Zakon o spodbujanju skladnega regionalnega razvoja \\
\hline 1990 (spremembe 1992) & 1999 \\
\hline $\begin{array}{ll}\text { - } & \text { demografsko ogorožena območja; } \\
-\quad & \text { demografsko ogrožena obmejna območja; } \\
\text { - } & \text { gorsko višinska območja; } \\
& \text { območja v prehodnem obdobju (do 1997) }\end{array}$ & $\begin{array}{l}\text { območja s posebnimi razvojnimi problemi (ekonomsko } \\
\text { šibka območja, območja s strukturnimi problemi in } \\
\text { visoko brezposelnostjo, razvojno omejevana obmejna in } \\
\text { območja z omejenimi dejavniki) }\end{array}$ \\
\hline $\begin{array}{l}\text { - } \quad \text { gibanje št. preb.; } \\
\text { indeks staranja }\end{array}$ & $\begin{array}{ll}\text { - } & \text { bruto osnova za dohodnino; } \\
\text { - } & \text { gibanje št. preb.; } \\
\text { - } & \text { delovnja registrirane brezposelnosti; } \\
\text { - } & \text { omejeni dejavno preb. v primarnem sektorju; } \\
& \text { obmejna lega }\end{array}$ \\
\hline krajevna skupnost, območje naselja & občina \\
\hline $\begin{array}{l}\text { Pomurje, Slovenske gorice, Podravje, Haloze, } \\
\text { Kozjansko, Posotelje, Posočje, Suha krajina, } \\
\text { Brkini, Zgornje Pokolpje, Bela krajina, Zgornja } \\
\text { Savinjska dol., Notranjska, celoten obmejni pas }\end{array}$ & $\begin{array}{l}\text { Pomurje, Slovenske gorice, Podravje, Haloze, Kozjansko, } \\
\text { Posotelje, Suha krajina, Zgornje Pokolpje, Bela krajina, } \\
\text { Zgornja Savinjska dolina, Notranjska, Spodnje Posavje, } \\
\text { nekatere občine (Jesenice, Lukovica,...) }\end{array}$ \\
\hline 61\% (1991-1995) & $57,2 \%$ \\
\hline 25\% (1991-1995) & $48,7 \%$ \\
\hline $\begin{array}{l}\text { - } \\
\text { pofinanciranje izdelave razvojnih } \\
\text { programov; } \\
\text { sofinanciranje izdelave projektne } \\
\text { dokumentacije; } \\
\text { - sofinanciranje razvoja lokalne } \\
\text { gospodarske infrastrukture; } \\
\text { - } \quad \text { spodbujanje gospodarskih naložb; } \\
\text { davčne olajšave; } \\
\text { ukrepi zdravstvenega in socialnega } \\
\text { varstva }\end{array}$ & $\begin{array}{ll}\text { - } & \text { subvencije; } \\
\text { - } & \text { ugodna poroštva; } \\
\text { - } & \text { davčne olajšave in oprostitve; } \\
\text { - } & \text { kapitalski vložki; } \\
& \text { prenos državnega premoženja v upravljanje } \\
\text { državnim skladom; } & \text { podeljevanje statusa ekonomskega območja; } \\
\text { - } & \text { podeljevanje statusa območij za pospeševanje } \\
& \text { zaposlovanja; } \\
\text { - } & \text { prenos državnega premoženja lokalnim skupnostim } \\
\end{array}$ \\
\hline
\end{tabular}




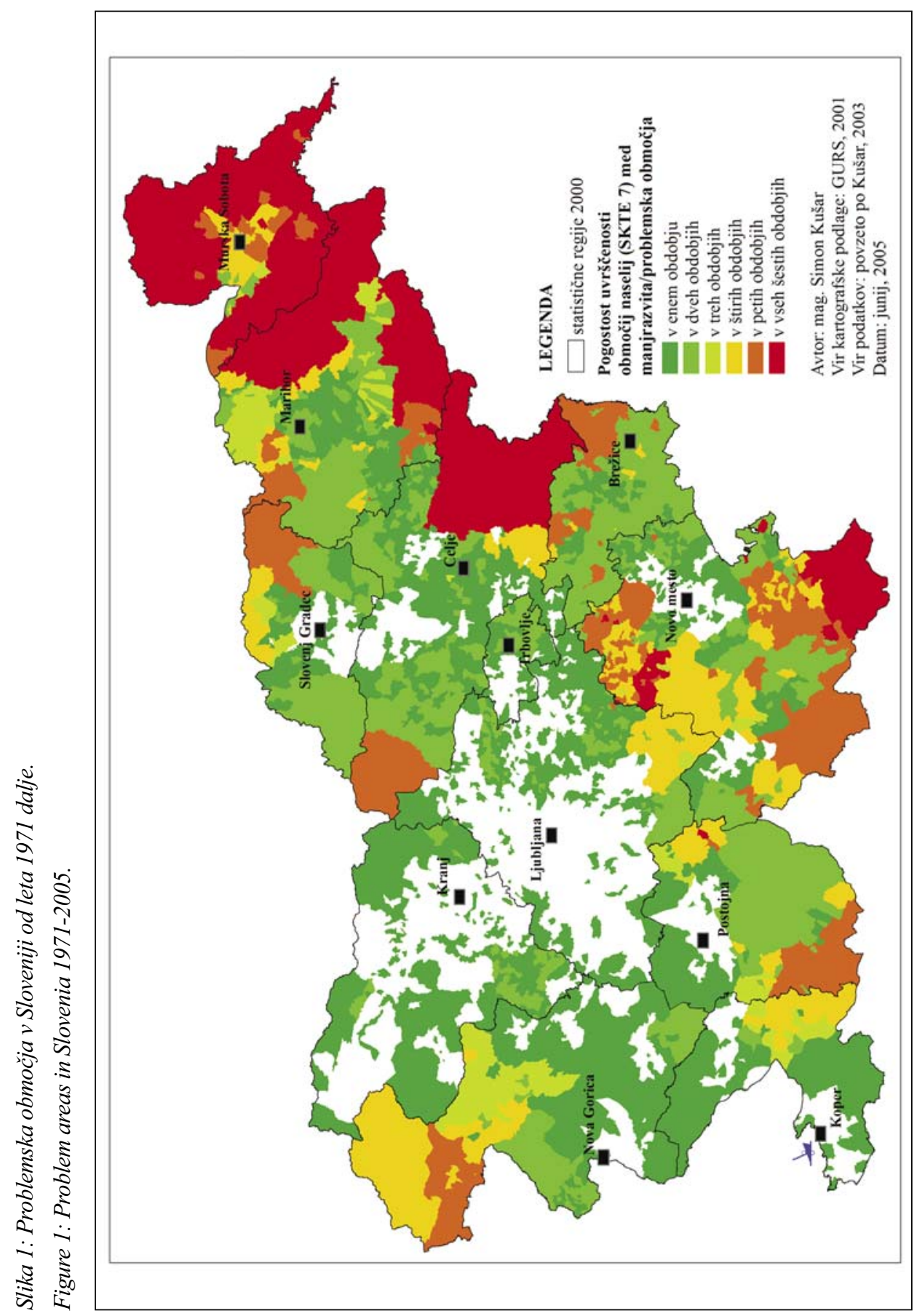


število ekonomskih, socialnih in infrastrukturnih meril je bilo združenih v posamezne skupine. Med manj razvita območja so bile prištete občine, ki so ustrezale postavljenim kriterijem ter krajevne skupnosti in občine, ki so izpolnjevale podobna merila, a z drugačnim odstopanjem od državnega povprečja. Postavljene so bile tudi nekatere relacijske omejitve $\mathrm{v}$ povezavi $\mathrm{z}$ določanjem zaokroženih problemskih območij. Določitev demografsko ogroženih območij je temeljila na kombinaciji indeksa staranja in rasti stalnega prebivalstva. Za določitev demografsko ogroženih obmejnih območij je bil spremenjen prag stopnje rasti prebivalstva. Posebna merila se se uporabljala za določitev gorsko višinskih območij. Merila za določitev območij s posebnimi razvojnimi problemi, kot jih opredeljuje Zakon o spodbujanju skladnega regionalnega razvoja iz leta 1999, so problematična $\mathrm{z}$ vidika njihovega števila in ponavljanja.

3. Drobljenje prostorskih enot za določitev manj razvitih območij od občin do območij naselij. Zakon o ukrepih za pospeševanje razvoja manj razvitih območij v Sloveniji je kot prostorsko enoto za določitev manj razvitih območij vpeljal občino. V Zakonu o pospeševanju skladnejšega regionalnega razvoja v Socialistični republiki Sloveniji so se za določitev manj razvitih območij uporabljale občine in krajevne skupnosti. V uredbah za določitev demografsko ogroženih območij po letu 1997 so le-ta določena na podlagi območij naselij. Občine so bile z vidika problemske homogenosti prevelika prostorska enota za opredeljevanje manj razvitih območij, medtem ko so »naselja premajhna enota za učinkovito izvajanje regionalnega razvoja« (Priprava..., 2000, str. 275).

4. Uspešnost regionalne politike je vprašljiva, saj so se v celotnem proučevanem časovnem obdobju med manj razvita območja prištevale iste regije $v$ Sloveniji.

Kušar (2003a) in Nared (2003) ob analizi učinkovitosti regionalne politike v Sloveniji citirata številne avtorje, ki gledajo razmeroma pozitivno na dosežene uspehe spodbujanja manj razvitih območij. V njih naj bi se izboljšala infrastrukturna opremljenost in gospodarska struktura, povečalo naj bi se število krajev z delovnimi mesti ter zvišala stopnja zaposlenosti. Ker pa so se v celotnem obdobju med problemska območja uvrščale iste regije v Sloveniji (Pomurje, Slovenske gorice, Podravje, Haloze, Kozjansko, Posotelje, Posočje, Suha krajina, Brkini, Zgornje Pokolpje, Bela krajina, Zgornja Savinjska dolina), je dejanska uspešnost spodbujanja regionalnega razvoja $v$ Sloveniji vprašljiva, predvsem od osemdesetih let dalje, ko so se razvojne razlike med regijami spet začele povečevati (Nared, 2003).

5. Prevelik delež prebivalstva in površine Slovenije, ki je sodil med manj razvita območja, za učinkovito spodbujanje razvoja.

V obdobju od leta 1971 do 1990 se je obseg manj razvitih območij stalno povečeval. Največji prostorski obseg je bil dosežen z uveljavitvijo pomoči demografsko ogroženim območjem, ko se je med problemska območja uvrščalo kar $61 \%$ površine Slovenije. V problemskih območjih je največji delež prebivalcev bival v času obstoja območij s posebnimi razvojnimi problemi (48,7\%). Tako velik obseg manj razvitih območij z vidika učinkovitosti regionalne politike ni ugoden, saj se relativno skromna sredstva namenjena spodbujanju manj razvitih območij močno razpršijo. Potrebna bi bila večja koncentracija sredstev. 
6. Podobni instrumenti regionalne politike, ki so se izvajali v manj razvitih območjih.

Za pomoč manj razvitim območjem so se v celotnem obdobju uporabljali podobni instrumenti: ukrepi davčne politike, sofinanciranje priprave in izvedbe razvojnih programov, razvoj infrastrukture ter spodbujanje gospodarskih naložb.

7. Programski pristop k spodbujanju skladnejšega regionalnega razvoja.

Vsi zakoni so predvideli, da razvoj manj razvitih območij temelji na razvojnih programih, ki jih pripravljajo občine, medobčinska združenja ali prizadeta območja. Ker se je država zavedala, da se manj razvita območja ne morejo zanašati le na lastne razvojne potenciale, jim je pomagala s finančnimi in davčnimi spodbudami ter s sofinanciranjem razvojnih programov.

8. Neformalen obstoj problemskih regij?

Zakoni o spodbujanju razvoja na problemskih območjih so kot izhodišče določanja manj razvitih območij vpeljale pojem »geografske zaključenosti«. Pri tem ni jasno ali gre za določanje problemskih regij (to je sklenjenih območij s skupnimi razvojnimi problemi), geografskih regij (kot problemska območja so opredeljene geografske regije) ali gre pri tem le za relacijsko omejitev, da morajo biti problemska območja stična. Vsekakor pa naj bi prizadeta lokalna območja skupaj reševala zadeve širšega pomena.

9. Načelo endogenega razvoja je v slovenski regionalni politiki prisotno že od leta 1971. Vsi zakoni predpostavljajo, da je v prvi vrsti za hitrejši razvoj odgovorna manj razvita občina oziroma manj razvito območje samo. Možnosti za hitrejši razvoj naj bi iskali predvsem pri sebi. »Osnova regionalne politike v Sloveniji je bila težnja po aktiviranju vseh potencialnih razvojnih možnostih na posameznih območjih« (Poročilo..., 1987, str. 5). Zato lahko trdimo, da je bilo načelo endogenega razvoja uvedeno v slovensko regionalno politiko že leta 1971.

\section{PRIHODNJI IZZIVI NA PODROČJU SPODBUJANJA RAZVOJA MANJ RAZVITIH OBMOČJJ V SLOVENIJI}

Tradicionalna regionalna politika, ki ji je do preloma stoletja sledila tudi slovenska, je svoje instrumente usmerjala $\mathrm{v}$ problemska območja. V nasprotju $\mathrm{z}$ njo temelji sodobna regionalna politika na spodbujanju razvoja $\mathrm{v}$ vseh regijah. Zadnje čase se v skladu $\mathrm{z}$ neoliberalno miselnostjo celo postavlja vprašanje, ali naj se država sploh še vpleta v ekonomski in družbeni razvoj regij ali naj vse prepusti delovanju tržnih mehanizmov, ki v skladu z ekonomsko teorijo $\mathrm{v}$ daljšem časovnem obdobju vodijo k izenačevanju vsakršnih razlik. Toda država je kljub vsem pomislekom dolžna skrbeti za najšibkejše člene na svojem ozemlju, saj mora zagotavljati minimum kakovosti življenja oziroma blaginje za vsakega prebivalca. V nasprotnem primeru se lahko sooči z resnimi gospodarskimi, političnimi in socialnimi posledicami. Obstoj problemskih območij v sistemu regionalne politike je zato še vedno potreben. Notranja razdelitev ozemlja za potrebe regionalne politike tudi ni v nasprotju z načeli skupne evropske regionalne politike, ampak lahko služi kot dopolnilo problemskim regijam, ki so določene za izvajanje posameznih ciljev evropske regionalne politike. 
Za učinkovito regionalno politiko na manj razvitih območjih bi bilo potrebno posvetiti večjo pozornost oblikovanju koncepta manj razvitih območij.

Prvo vprašanje, na katerega bi bilo potrebno odgovoriti, je obseg manj razvitih območij. Dosedanje izkušnje kažejo, da prevelik obseg ni smiseln, saj se skromna finančna sredstva razpršijo na preveliko območje, kar posledično vpliva na manjšo učinkovitost regionalnoplanerskih instrumentov. $Z$ vidika obsega in razprostranjenosti manj razvitih območij se zdi najustreznejša rešitev, ki jo je prinesel prvi zakon za pospeševanje manj razvitih območij leta 1971, ko je bilo med njih uvrščena manj kot petina območja Republike Slovenije. Podrobnejši pogled pa pokaže, da je ta obseg verjetno preskromen. Najustrezneje bi bilo, če bi manj razvita območja obsegala med četrtino in tretjino površine Slovenije.

Problem predstavlja tudi nehomogenost manj razvitih območij. Kušar (2003b) ugotavlja, da lahko med območji oziroma regijami, ki zaostajajo v razvoju, razlikujemo vsaj med dvema podtipoma: manj razvita območja, ki zajemajo predvsem podeželjska območja, ki niso bila $\mathrm{v}$ popolnosti deležna industrializacije in modernizacije, ter regije $\mathrm{v}$ industrijskem zatonu, za katere je značilen gospodarski zastoj nekdaj propulzivnih panog. Oba podtipa kljub številnim podobnostim potrebujeta različne ukrepe. Pri opredeljevanju prednostnih območij regionalne politike bi bilo zato potrebno določiti (vsaj) dva tipa manj razvitih območij.

Ob tem pa se zastavi novo vprašanje: katera merila uporabiti za njihovo določitev? Premajhno število zagotovo ni primerno, kar se je pokazalo v primeru demografsko ogroženih območij. Večje število meril pa tudi ni ugodno. Izbrana bi morala biti tista, ki prikazujejo temeljne razvojne probleme značilne za manj razvita območja. Od ekonomskih meril bi lahko uporabili delež zaposlenih, ki so zaposleni v neperspektivnih gospodarskih panogah, kot so kmetijstvo, tekstilna in usnjarska industrija. Od meril, ki prikazujejo stanje človeške družbe in izkoriščenost človeškega kapitala, bi bila lahko uporabljena registrirana stopnja brezposelnosti in migracijski saldo, od meril prostorskega in okoljskega razvoja pa se zdita najustreznejši merili oddaljenost od centralnih naselij različnih stopenj in prisotnost komunalne infrastrukture. Bistveno pri opredeljevanju meril za določanje manj razvitih območij je njihova enostavnost, nepovezanost in preverljivost. Ista merila se morajo uporabljati v daljšem časovnem obdobju (vsaj 10 let), da se lahko objektivno ocenijo učinki regionalne politike.

Naslednje vprašanje je povezano s prostorskim konceptom manj razvitih območij. Do sedaj so se uporabljala območja. Med problemska območja so se prištevale vse občine, krajevne skupnosti in/ali območja naselij, ki so dosegala postavljen prag za uvrstitev med problemska območja. V dosedanji zakonodaji je bila prostorska sklenjenost zasledovana tako, da so se med manj razvita območja uvrščale tudi prostorske enote, ki so bile obkrožene z manj razvitimi območji. V prihodnjih raziskavah bi bilo potrebno razmisliti, ali je ta način primeren. Sodobna regionalna politika namreč postavlja v ospredje regije, to je večje prostorske enote, ki imajo svojo identiteto, skupne probleme in skupne poglede na prihodnost. Zato bi bilo verjetno primerneje manj razvita območja določati na podlagi regij, to je na podlagi večjih prostorskih enot. Tu pa nastopi nov problem. Slovenija je geografsko in razvojno zelo raznolika, zato velike regije ne pridejo $\mathrm{v}$ poštev. Po drugi strani pa velike regije omogočajo uspešnejše tekmovanje na globalnem trgu in lažje pridobivanje sredstev skupne evropske regionalne politike. Zato se kot rešitev ponuja subregionalna raven, ki zajema sklenjene prostorske enote znotraj večje regije. 
Kateri instrumenti naj se izvajajo v prednostnih območjih regionalne politike? Izbira ni prav velika. Finančni instrumenti zagotovo ostanejo. Posebno pozornost pa bi bilo potrebno posvetiti endogenemu razvoju, ki je še posebej močno izpostavljen v sodobni regionalni politiki. Pri tem pa se zastavi zanimivo vprašanje: v kolikšni meri lahko razvoj v problemskih regijah sploh sloni na lastnih virih in kolikšen delež razvojne pomoči naj prispeva država? Pri uspešnemu endogenem razvoju odigrajo pomembno vlogo količina virov (naravni, človeški), identiteta, ki omogoča medsebojno povezovanje na regionalni ravni z oblikovanjem različnih formalnih in neformalnih mrež, psihološko stanje $\mathrm{v}$ regiji (za problemske regije so pogosto značilni pasivnost, lokalizmi, upor institucijam, kriminal, vandalizem) in predvsem razvojno inovativno jedro, ki bo služilo kot temelj prihodnjega regionalnega blagostanja. Če so endogeni dejavniki razvoja slabo razviti, naj bi jim $\mathrm{k}$ aktiviranju pomagala država $\mathrm{z}$ organizacijsko pomočjo pri pripravi in izvedbi regionalnih razvojnih programov in z ustreznimi finančnimi viri.

\section{SKLEP}

Slovenija ima večdesetletne izkušnje na področju spodbujanja razvoja manj razvitih območij. Prvi pravni akt, ki je natančno opredeljeval prostorski obseg manj razvitih območij, njihov način opredeljevanja in instrumente, ki se bodo izvajali v njih, je bil sprejet že leta 1971. V celotnem obdobju je bilo več poskusov, kako čim ustrezneje opredeliti manj razvita območja. Dejansko učinkovitost dosedanje regionalne politike je težko izmeriti, saj ex-post vrednotenje ni bilo vključeno v planerski sistem. $\mathrm{O}$ uspehu dosedanje regionalne politike bi se lahko podvomilo zaradi tega, ker so se med manj razvita območja $\mathrm{v}$ celotnem obdobju aktivnega poseganja v razvoj regij uvrščale iste pokrajinske enote v Sloveniji, vendar je potrebno poudariti, da so se merila za njihovo določanje pogosto spreminjala. Med dosežke regionalne politike pa lahko prištevamo programski pristop in načelo endogenega razvoja, ki je v konceptu sodobne regionalne politike še posebej poudarjeno.

Aktivnostiprispodbujanju razvoja regij senadaljujejo, saj bodosedanji sistem spodbujanja skladnega regionalnega razvoja v kratkem doživel večje spremembe. Vlada je konec junija 2005 sprejela nov predlog zakona o spodbujanju skladnega regionalnega razvoja, ki je bil že posredovan v obravnavo in sprejem v Državnem zboru. Predlog zakona vsebuje tudi nov sistem opredelitve prednostnih območij delovanja regionalne politike. Za določitev razvitosti razvojnih regij predvideva uporabo indeksa razvojne ogroženosti. Predlog zakona govori tudi o »prednostnih območjih«, ki bodo natančneje opredeljena v Strategiji regionalnega razvoja Slovenije. Z njimi so mišljena območja znotraj razvojnih regij, ki najbolj zaostajajo v razvoju oziroma se soočajo z velikimi strukturnimi problemi. V njih se bodo izvajali posebni ukrepi regionalne politike, pri dodeljevanju spodbud pa jih bodo morali upoštevati vsi proračunski uporabniki.

Slovenija je z geografskega vidika zelo pestra. Zato bodo vedno obstajale pomembne razlike v stopnji doseženega razvoja med regijami. Naloga regionalne politike pa je, da inter in intraregionalne razlike ostajajo na neki sprejemljivi ravni. 


\section{Literatura}

Kušar, S., 2003a: Problemska regija kot element za zasnovo regionalnega razvojnega programa: magistrsko delo. Ljubljana, Filozofska fakulteta, Oddelek za geografijo, 141 str.

Kušar, S., 2003b: Zasavje: a problem region. V: Regionalno razvojna problematika Bosne i Hercegovine i susjednih zemalja u procesu približavanja EU. Mednarodni naučni seminar. Tuzla, Prirodno-matematićki fakultet, Odsjek za geografiju, str. 201-212.

Nared, J., 2003: Legislation in the Field of Regional Policy in Slovenia and Analysis of its Spatial Impact. Acta Geographica Slovenica, 43, 1, str. 85-110.

Poročilo za sintezno študijo: Oblikovanje kompleksnega modela skladnejšega regionalnega razvoja SR Slovenije in manj razvitih območij. Raziskovalni projekt: Skladnejši regionalni razvoj Slovenije in manj razvitih območij. 1987: Ljubljana, Urbanistični inštitut SR Slovenije, str. 1-19.

Predlog zakona o spodbujanju skladnega regionalnega razvoja. 23. junij 2005. Ljubljana, 48 str. (objavljeno na http://www.gov.si/svrp/5novo/ln-231.html, citirano 12. julij 2005).

Priprava strokovnih podlag za Strategijo regionalnega razvoja Slovenije. 2000: Ljubljana, Inštitut za ekonomska raziskovanja, 302 str.

Vrišer, I., 1998: Regionalni razvoj slovenskih pokrajin. Regionalno prostorsko planiranje - praksa in izzivi. Zbornik mednarodnega strokovnega posveta. Bled, str. 63-73.

\section{LESS DEVELOPED AREAS AS AN ELEMENT OF BALANCED REGIONAL DEVELOPMENT POLICY IN SLOVENIA: PAST EXPERIENCES AND FUTURE CHALLENGES}

\section{Summary}

Slovenian experiences with place prosperity policy go a few decades back. Less developed areas were introduced in 1971 for the first time and since then they have been continuously used as an instrument of regional policy. Some basic characteristics of promoting balanced regional development policy and the development of less developed areas in particular, can be summarized through the following statements:

1. orientation of Slovenian regional policy towards less developed areas has been practiced since 1971, when the first Balanced Regional Development Act was adopted;

2. indicators used for determination of problem areas were changed frequently (every 3 to 5 years);

3. from communes to areas of settlements: spatial areas used as a basis for the delineation of less developed areas were getting smaller;

4. the efficiency of regional policy is doubtful: problem regions were more or less the same geographical units in all periods;

5. the percentage of Slovenian territory (and consequently population) eligible for special attention of Slovenian regional policy was too high ranging from $18,9 \%$ in $1971-1975$ to $57,2 \%$ after 2000 ; 
6. the use of similar instruments as a part of regional policy throughout the whole period: tax-revenues, co financing of preparation and implementation of development programs, development of infrastructure, stimulation of economic investments;

7. programming: the development of less developed areas should have been achieved through preparation and implementation of development programs;

8. geographical adjacency of problem areas; informal existence of problem regions?;

9. less developed areas with their strengths and opportunities should themselves shoulder the responsibility for their development: endogenous development was introduced into Slovene regional policy already in 1971.

Future challenges in the creation of new system of promoting the development of less developed areas are primarily connected with:

1. the decision to extend the less developed areas, which should vary between one quarter and one third of the Slovene territory/population;

2. heterogeneity of less developed areas; at least two subgroups of less developed areas can be defined, namely, less developed rural areas and industrial areas in decline. For both subgroups different measures should be taken;

3. the creation of new set of measures which should be used for defining less developed areas;

4. the selection of the most proper spatial unit for the delineation of problem areas; according to contemporary regional policy, globalization trends and heterogeneity of Slovene regions sub regions should be introduced;

5. the selection of regional policy measures.

The newest version of the new Balanced Regional Development Act form June, 2005 brings new system of less developed areas which will be defined inside development regions.

Slovenia is geographicaly very diverse. This is the reason, that interregional disparities will exist in the future, too. But regional policy has to assure that stay on the still acceptable level. 